\title{
Review
}

\section{Counter-history of the present: Untimely interrogations into globalization, technology, and democracy}

\author{
Gabriel Rockhill \\ Duke University Press, Durham, NC, 2017, xii + 148 pp., \\ ISBN: 978-0822369769
}

Contemporary Political Theory (2019) 18, S24-S27. https://doi.org/10.1057/s41296018-0200-0; published online 2 February 2018

The idea that we live in the new is, or at least over the course of the last few centuries has become, a pervasive feature of 'Western modernity'. 'Our' new today is characterized by pictures of the inexorable growth of connectivity, the networks of trade and communication that cross national borders and social boundaries, and of the universality of 'democracy' as the form of political organization that both best reflects and promotes the further development of these connections. Of course, these pictures are merely perspectives on a reality that can be represented very differently. If Gabriel Rockhill's book was solely concerned to show the partiality of the pictures of globalization, the emancipatory capacity of the technologies associated with the exponential growth of computing power, and the 'universality' of what passes for democracy, then it would join a long list of critical commentaries on these subjects that share in common the desire to reveal more completely the single reality that these representations distort. What makes Rockhill's work stand out is that he brings into question the very idea that the purpose of a critique of the concepts of globalization, technology, and democracy should be to disclose the truth about 'our time' at all. His 'counter-history' is a 'double counter-history': it seeks not just to contest the 'imaginary' that links together these three concepts in picturing our time, but to challenge the very idea that we should conceive of the 'present' as a time in which we live (p. 3). The present is not a single time, 'our' time, but is constituted in the three related dimensions of temporality, spatiality, and sociality (hence the need not just for a counter-history of the present but also a counter-geography and counter-sociology (p. 4). His interrogations are, then, 'untimely' in the sense that they do not proceed purely from the temporal dimension, on the surmise that the present is the highest-vantage point for our understanding of the past and the way that we live now. To make that assumption is to buy into the very form of the historico-political imaginary that celebrates (or

(c) 2018 Macmillan Publishers Ltd., part of Springer Nature. 1470-8914 Contemporary Political Theory Vol. 18, S1, S24-S27 www.palgrave.com/journals 
indeed wishes to simply reverse) the March through history of trade, technology, and 'democracy'.

I will return to the value of Rockhill's method at the end of the review. His application of it to the concepts of globalization, technology, and democracy yields some important and persuasive insights. With regard to globalization, it is not just a case of acknowledging the unevenness of its effects (less than half the world's population have access to the internet for example (p. 12)), but of questioning the idea that the word 'globalization' is capable of referring to the existential status of the world. Rather, 'globalization' designates both a word and a set of practices economic, technological, social, and political - that are designed to shape the world in the image of the word. Our objective should not be to position ourselves 'in' the 'realist' debate on globalization, i.e. whether the word represents a real phenomenon. In the literature of social science, there are very plausible pictures for and against globalization as such a phenomenon, and Rockhill is surely right that it neither designates a 'unique or differentiated reality', nor does it simply construct a 'false reality' (p. 27). Instead, we should approach globalization as part of the dominant imaginary: the imaginary of a 'neoliberalism' that is equally incapable of being confirmed or falsified as a picture of reality. In tracing the conjuncture of this imaginary, Rockhill makes the plausible claim that it involves the re-habilitation by economic liberals of a 'vulgar' Marxism: the belief in a teleological, linear historical development, in which techno-economic progress leads to the 'end of history', with the universal embrace not of communism, but of neoliberal democracy.

The present generation's assumption of the development of the productive forces as an autonomous driver of human history (not, as Rockhill very correctly points out, the view that Marx himself held of history) is confounded if we follow Rockhill's approach to technology. He sets himself against a variety of thinkers such as Gilles Deleuze, François Lyotard, and Bernard Stiegler - who claim that we can periodize the present as an age of technology (pp. 33-43). All assume the independence of technology; however, to present the question of technology as involving a choice between ascribing to it autonomy (technological determinism) or heteronomy (determined technology) is to fall back on a much-simplified picture of its complex reality. Equally, the choice of whether to be a technophobe or technophile is the wrong one. This is because, as Rockhill argues persuasively, there is good reason to ask whether there is such a 'thing' as technology at all. To see technology as 'an element in the world' is an error. We should rather consider technology as part of a 'social ecology', it being located only in places and social relations, rather than standing outside of them as either an 'independent force' or simple 'instrument for use' (p. 45).

The longest chapter of the book - on democracy - provides a powerful challenge to the idea that we should consider the concept as one of value (both in the sense of being a value-concept and a valuable concept). Political theorists would do well to follow Rockhill here, because in this field they are frequently guilty of a misguided

(C) 2018 Macmillan Publishers Ltd., part of Springer Nature. 1470-8914 Contemporary Political Theory Vol. 18, S1, S24-S27 
complicity with the 'dominant political imaginary': having demonstrated the grounds on which 'neoliberal' democracy is not democracy at all, they often too readily fall back on fuzzy assertions of the value of a 'true' democracy, one that somehow captures a picture of a reality, in which a 'sovereign' people, divested of its shackles, can really govern itself. Of course, as Rockhill suggests, the reality of government and self-government is profoundly more complicated, and can be seen as a spatially and socially constituted ground of contestation of 'democratic' political imaginaries. This is a 'timely' (no pun intended) reminder that, 'Democracy as such does not exist. There are only diverse sociohistorical practices qualified as democratic from specific points of view' (p. 60). In providing an 'intransitive history' of democracy, Rockhill shows convincingly that we should abandon any understanding of democracy developing in linear fashion on the single axis of time, and rather see it as operating across temporal, spatial, and social dimensions in a way that suggests the mutability and contingency of democratic practices of government. The effect of such an approach is not to lead us to a dismissal of 'democracy', but rather to give us a better orientation towards its practical character and provide us with resources for a critique of actually existing democracy (pp. 79-95). Such a view of democracy also has the added benefit of bringing under suspicion the much vaunted - and in recent political theory far too celebrated - 'purity' and autonomy of the political (pp. 95-102).

Rockhill has written a provocative and highly readable book (indeed, it is even something of a page-turner). If there is a small reservation, it is that the approach of a 'double' counter-history is hardly new or surprising. To be fair, Rockhill does not advertize it as such, and a passage (p. 53) on the importance of 'radical historicism' brings to mind the Foucauldian strategy of a 'history of the present'. The objective of 'bringing to light the historical contingency of the reigning political imaginary and, more generally, of the nearly systematic valorization of democracy in the socalled Western world' sounds consistent with the kind of 'genealogical' approach to modern politics and democracy that aims to "lay the foundations for a historical critique by denaturalizing the normative structures and unquestioned intellectual givens of the moment' (p. 53). Nonetheless, what is arresting about the book is the aplomb with which Rockhill goes about this task of disclosing the contingency of the present political imaginary. A review of this length cannot do justice to the political force of this critique. But that force, in general terms, lies in the relentless exposure of neoliberalism's flattening out of 'time, space, and society' (p. 104). If the force of political critique is not to be found in the revelation of a single reality marked out by being 'now' - which would be simply to recapitulate the homogenizing and destructive disposition of neoliberal practices of government - it may be located in the recognition of the multiple and contingently related realities of time, space, and social relations. A political theory that is sensitive to the way in which political imaginaries are constituted in and can be challenged through the practices connected across these realities, is likely to have a greater impact on those 
practices than one that busies itself with the fruitless search for a universal ideal of a democracy whose time can never come, precisely because its place lies outside of time, space, and society.

Jason Edwards

Birkbeck, University of London, London WC1E 7HX, UK j.edwards@bbk.ac.uk 